\title{
Settlement of disputes upon termination of employment contract by agreement of parties
}

\author{
Nina Semeryanova ${ }^{1 *}$, Ilona Vasenina $^{2}$, Ibragim Aitov ${ }^{3}$, and Elizaveta Sedelnikova ${ }^{4}$ \\ ${ }^{1}$ South Ural State University (National Research University), Nizhnevartovsk Branch, Mira str., 9, \\ Nizhnevartovsk, 628600, Russia \\ ${ }^{2}$ Nizhnevartovsk city court, Pobeda str., 4, Nizhnevartovsk, 628606, Russia \\ ${ }^{3}$ Tyumen Industrial University (Nizhnevartovsk Branch), Lenina str., 9/2, Nizhnevartovsk, 628616, \\ Russia \\ ${ }^{4}$ Tyumen Industrial University, Volodarskogo str., 38, Tyumen, 625000, Russia
}

\begin{abstract}
The article discusses features of legal regulation of these legal relations, analyzes judicial practice. The leading research approach includes such scientific methods as dialectics, analysis, synthesis, and deduction, comparative legal and formal legal methods. The authors conclude that termination of severance pay stipulated by the agreement on termination of the employment contract does not indicate its illegality. The employee must be guaranteed the right to receive financial support for the period of job search, as well as the fulfillment of a voluntary obligation by the employer. The absence of acts providing for compensation payments in the organization is not a reason for refusing to pay severance pay. The conclusion of an agreement on termination of an employment contract has several advantages, provided that the obligations undertaken by the parties are met in good faith.
\end{abstract}

\section{Introduction}

The basic principles of legal regulation of labor relations and other relations directly related to them are the principles of freedom of work, including the right to work that everyone freely chooses or freely agrees to, a combination of state and contractual regulation, ensuring the right of everyone to protection of his labor rights and freedoms by the state, including judicial protection, as well as the obligation of the parties to the employment contract to comply with the terms of the contract. Freedom of work is manifested in the contractual nature of labor, in the freedom to conclude and terminate an employment contract on certain conditions based on the voluntary and agreed will of the parties. One of the main tasks of labor legislation is to create the necessary legal conditions to achieve optimal coordination of interests of parties to labor relations.

By virtue of provisions of Article 9 of the Labor Code of Russian Federation (hereinafter referred to as the Labor Code of Russian Federation), these relations can be regulated by concluding, amending, supplementing collective agreements, agreements, labor contracts by employees and employers that cannot contain conditions restricting

*Corresponding author: nina_777s@mail.ru 
rights or lowering the level of employee guarantees compared to established by labor legislation and other regulatory legal acts containing labor law norms. Guarantees and compensations related to termination of an employment contract are enshrined in Chapter 27 of the Labor Code of Russian Federation and apply primarily to workers as the most vulnerable side of labor relations.

In accordance with Art. 57 of the Labor Code of Russian Federation, labor contract may provide additional conditions that do not worsen the position of the employee in comparison with the established labor legislation and other regulatory legal acts containing labor law, collective agreement, agreements, local regulatory acts. Article 178 of the Labor Code of Russian Federation provides the opportunity to establish additional cases of severance pay, as well as their increased amounts, with an employment or collective agreement. The agreement on termination of an employment contract is an integral part of the employment contract, therefore, the absence of mention of this in art. 178 of the Labor Code of Russian Federation is quite reasonable.

Thus, the legislation allows the possibility of concluding agreements on termination of the employment contract on the terms agreed by the parties. However, the existing judicial practice indicates that most often courts recognize the refusal of the employer to pay the employee the severance pay stipulated by the agreement on termination of the employment contract. As Slesarev S. notes, the vicious practice of unjustified infringement on already weak freedom of contract in labor relations is obvious. [1]

Theoretical basis of the study includes scientific works of pre-revolutionary scientists who conducted research in the field of labor law (Voitinsky I.S., Pasherstnik A.E., Tal L.S.) and modern ones who examined the issues of concluding, amending and terminating an employment contract (Alexandrov N.G., Baglay M.V., Ginsburg L.Ya., Kaskel V., Livshits R.Z., Skobelkin V.N., Khokhlov E.B., Chucha S.Yu.).

Problems of termination of the employment contract by agreement of the parties were considered by such authors as Glukhov A.V., Konyakhin N., Martynova T.N., Paryagina O.A., Povarov Yu.S., Sgibneva O.V., Trifonova E.Yu., Chernyakov M.Yu. and others. Currently, this issue remains insufficiently studied and gives rise to contradictions in judicial practice.

Empirical basis is constituted by the Constitution of Russian Federation, the Labor Code of Russian Federation, judicial practice: Determination of the Judicial Collegium for Civil Cases of the Supreme Court of Russian Federation of 04.12.2017 N89-KG17-15, Appeal determination of the Moscow City Court of 08/14/2019 in case N 33-36325 / 2019, Appeal ruling of the Moscow City Court of May 28, 2019 in the case N 33-21451 / 2019, Appeal ruling of the Saratov Regional Court of May 16, 2019 in the case of N 33-3490 / 2019, etc.

Novelty of the study lies in the assessment of current state, as well as formulation and justification of problems of practical application of labor laws that regulate relations in this area.

\section{Methods}

The following scientific methods were used in the work: dialectics, analysis, synthesis, formal legal and comparative legal method. An analysis of legal regulations of relations in the field of termination of an employment contract by agreement of the parties made it possible to comprehend legislative contradictions and gaps in the regulation of these relations. The dialectical method allowed a comprehensive study of the essence of existing contradictions. The use of the comparative legal method helped to compare various approaches to the interpretation of labor law and to develop their own position for resolving disputes on the payment of severance pay upon termination of an employment contract by agreement of the parties. 


\section{Results}

Current legislation established that an agreement on termination of the employment contract may provide, in addition to those specified in Art. 178 of the Labor Code of Russian Federation, additional cases of severance pay. However, quite often such payments are not made upon dismissal by agreement of the parties by the employer, which forces workers to apply for judicial protection of their rights. As the analysis of judicial practice shows, the result of dispute resolution is not always in favor of an employee.

1. The disputed payment, in the opinion of courts, does not apply to guarantees and compensations to be provided upon dismissal of an employee under paragraph 1 of Art. 77 of the Labor Code of Russian Federation by agreement of the parties, is not a severance pay and is not aimed at reimbursing costs associated with performance of labor or other duties. In addition, the courts believe that the payment of compensation to an employee, including termination of an employment contract concluded with him, must be provided for by law or organization's wage system established by the collective agreement, local regulations adopted in accordance with labor law and other regulatory legal acts containing labor law standards (determination of the Judicial Collegium for Civil Cases of the Supreme Court of Russian Federation of 04.12.2017 N89-KG17-15, Appeal Definition Moscow City Court of 08/14/2019 in case No. 33-36325 / 2019, Appeal determination of the Moscow city court of 05/28/2019 in case No. 33-21451 / 2019, Appeal determination of the Saratov regional court of May 16, 2019 in case No. 33-3490 / 2019 and others).

It is impossible to fully agree with this approach of the courts, since the severance pay, in its essence, is a compensation payment that guarantees the employee compensation for adverse consequences associated with the termination of the employment contract.

2. It is worth agreeing with the court's opinion that compensation payments to an employee related to termination of an employment contract should be provided for by law or the organization's remuneration system established by the collective labor agreement and local regulations. However, we believe that the responsibility for the existence of such provisions in the acts of the organization should lie with the employer in case that termination of severance pay is included in the agreement on termination of the employment contract. That is why, an employee cannot be denied the severance pay stipulated by the agreement on the grounds that the organization does not have normative acts providing for compensation payments. Offering the employee to conclude an agreement on termination of the employment contract with compensatory payments and, knowing that such payments are not provided for in the organization by internal documents, the employer thereby misleads the employee. Such behavior is unfair and an obvious abuse of law. In this connection, we propose to introduce administrative liability for legal entities to exclude such situations.

3. When implementing guarantees provided by the Labor Code of Russian Federation to employees in case of termination of the employment contract, the general legal principle of inadmissibility of abuse of the right, both on the part of the employer and on the part of the employee, must be observed. In this regard, we believe that in case of termination of the employment contract by agreement of the parties, it would be advisable to apply the analogy of the law, in particular Art. 349.3 of the Labor Code of Russian Federation on limitation of the size of severance pay, compensation and other payments in connection with termination of employment contracts for certain categories of workers. This article prohibits the inclusion in the agreement on termination of the employment contract of conditions for payment of severance pay, compensation or any other payments in any form to managers, their deputies, chief accountants and members of collegial executive bodies of state corporations, state-owned companies, and business enterprises companies with more than fifty percent of shares (stakes) in the authorized capital of which are state or municipal 
property, as well as their deputies, chief accountants of state non-budgetary funds of the Russian Federation, territorial compulsory medical insurance funds, state and municipal institutions, state and municipal unitary enterprises. Legislators correctly classify this category as persons who are able to abuse their rights when receiving compensation payments. In this regard, we consider it necessary to extend the scope of this article to managers, their deputies, chief accountants of all corporate organizations, regardless of participation of Russian Federation.

4. An agreement on termination of an employment contract subject to the termination of severance pay cannot be invalidated as not complying with the requirements of the law, as well as if there are signs of abuse of law, since the norms of civil law are not subject to application when considering an individual labor dispute. In addition, in the labor legislation there is no concept of invalidity of an employment contract.

The algorithm for settlement of disputes regarding the additional severance payments provided for upon termination of an employment contract by the agreement of the parties is presented in Figure 1.

5. The possibility of termination of an employment contract by agreement of the parties established by the labor legislation is an effective economically feasible tool that allows the employer to simplify the procedure for termination and guarantees the employee financial security upon termination, subject to the conscientious fulfillment of obligations undertaken.

Table 1 presents the benefits of terminating an employment contract by agreement of the parties from the perspective of the employer and employee.

Table 1 the Benefits of termination of the employment contract by agreement of the parties from the position of the employer and employee

\begin{tabular}{|c|c|c|}
\hline № & For employer & For employee \\
\hline 1 & Simplified termination procedure & $\begin{array}{c}\text { Possibility to agree on conditions for receiving } \\
\text { compensation }\end{array}$ \\
\hline 2 & Minimizing the cost of dismissal & $\begin{array}{c}\text { Obtaining financial security while searching for } \\
\text { a new job }\end{array}$ \\
\hline 3 & $\begin{array}{c}\text { Ability to terminate an employment } \\
\text { contract at any time }\end{array}$ & $\begin{array}{c}\text { An agreement on termination of an employment } \\
\text { contract cannot be recognized as invalid }\end{array}$ \\
\hline
\end{tabular}

\section{Discussion}

The issue of the nature of payments provided for by the agreement on termination of the employment contract is debatable. Some courts do not attribute disputed payments to guarantees and compensations to be provided upon dismissal of an employee under paragraph 1 of Art. 77 of the Labor Code of Russian Federation by agreement of the parties, believing that they are not severance pay and are not aimed at reimbursing the costs associated with the performance of labor or other duties. Others believe that disputed payments are inherently compensatory, since the norm of Art. 178 of the Labor Code of Russian Federation is not unreasonably placed in Chapter 27 of the Labor Code of Russian Federation "Guarantees and Compensations to Employees Related to Termination of an Employment Contract". It seems that the payments stipulated by the agreement on termination of the employment contract are compensatory in nature, since they guarantee the compensation for the adverse consequences associated with termination of the employment contract. Adverse consequences are expressed in the fact that the employee is under financial burden for the period of searching for a new job. Upon dismissal, the employee is the economically weaker side compared to the employer, so he should be guaranteed the receipt of those payments to which he agreed. Confirmation of our position 
is determined by the provisions of Art. 164 of the Labor Code of Russian Federation, where definitive rules are established that disclose the concepts of "guarantee" and "compensation". Guarantees are the means, methods and conditions by which the exercise of the rights granted to employees in the field of social and labor relations is ensured. Compensations are cash payments established in order to reimburse employees for the costs associated with the performance of their labor or other duties stipulated by the Labor Code of Russian Federation and other federal laws. In addition, as Fomina M. correctly noted, these payments have the same legal nature and social purpose.

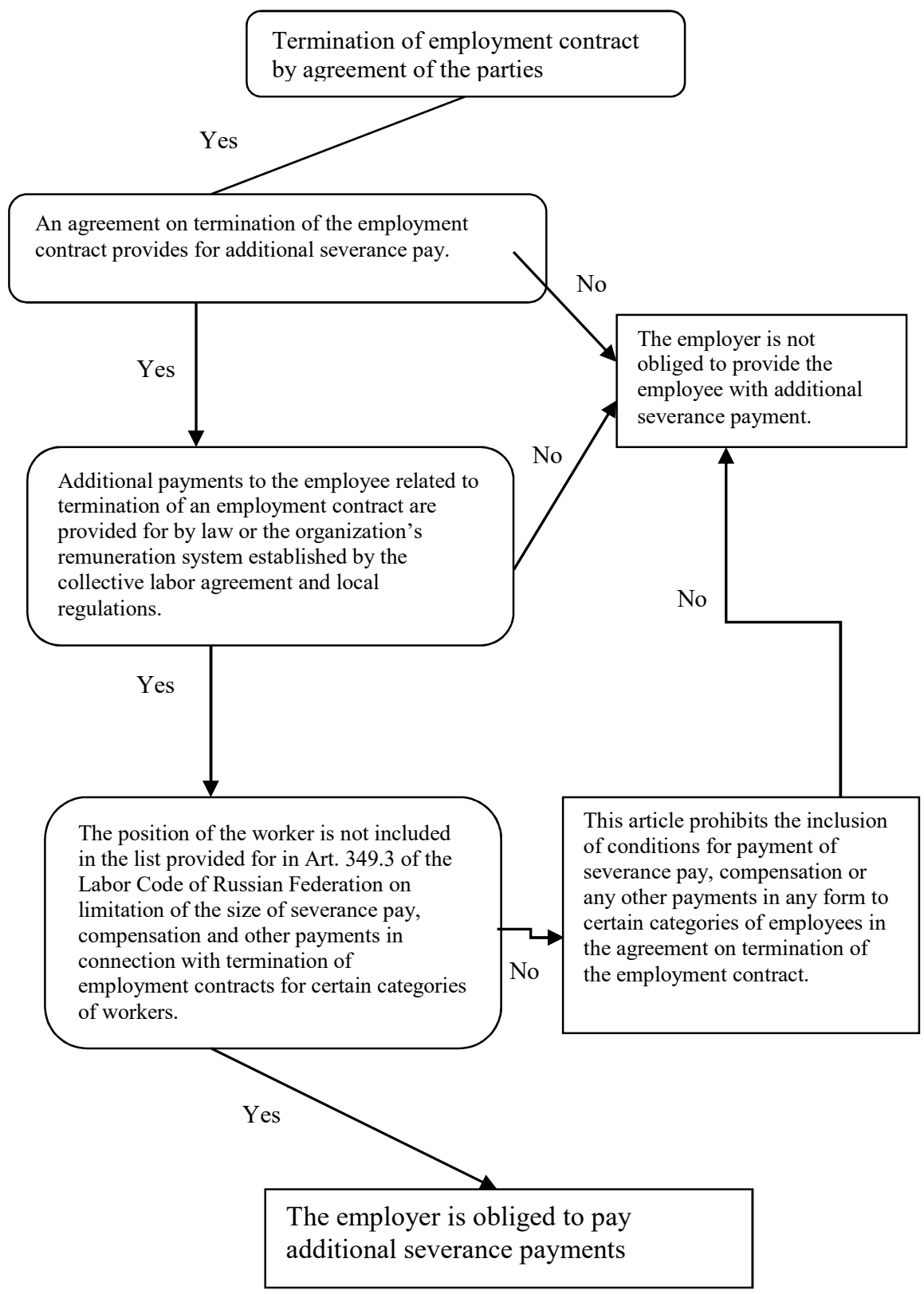

Fig. 1. Algorithm for settlement of disputes on additional severance payments by termination of employment contracts by the agreement of the parties. 


\section{Conclusion}

1. An agreement on termination of an employment contract between an employee and an employer is an agreement to terminate an employment contract in accordance with clause 1, part 1, Art. 77 of the Labor Code of Russian Federation, according to which the employer voluntarily assumes the obligation to pay the employee a severance pay.

2. Inclusion of the condition for the payment of employee severance pay in the agreement of termination of the employment contract does not indicate its illegality. The employee is confident that termination of employment contract will occur on conditions specified by the parties, that he participates in bona fide and legal relations. Failure to fulfill a voluntary obligation by the employer leads to an infringement of the employee's right to receive financial guarantees for the period of job search.

3. An employee may not be denied the severance pay stipulated by the agreement on the grounds that the organization does not have normative acts providing for compensation payments.

\section{References}

1. C.O. Trevor, R. Piyanontalee, Annual Review of Organizational Psychology and Organizational Behavior 7, 181-211 (2020) DOI: 10.1146/annurev-orgpsych-012119045343

2. F. Belloc, Metroeconomica 70(4), 641-654 (2019) DOI: 10.1111/meca.12245

3. A. Todolí-Signes, Transfer 25(4), 465-481 (2019) DOI: $10.1177 / 1024258919876416$

4. P. Sarkar Structural Change and Economic Dynamics 52, 374-381 (2020) DOI: $10.1016 /$ j.strueco.2019.12.010

5. A. Dilfuza, S. Bobur, S. Gulnar, B. Khurshida, International Journal of Innovative Technology and Exploring Engineering 9(1), 3232-3238 (2019) DOI: $10.35940 /$ ijitee.A9162.119119

6. U. Filatova, N. Semeryanova, S. Suslova, A. Gabudina, A. Kopytova, E3S Web of Conferences 91, 08071 (2019) DOI: https://doi.org/10.1051/e3sconf/20199108071

7. C. Signoretto, J. Valentin, European Journal of Law and Economics 48(2), 241-265 (2019) DOI: 10.1007/s10657-019-09625-6

8. M.C. Martinez, F.M. Fischer, International Journal of Environmental Research and Public Health 16(17), 3143 (2019) DOI: 10.3390/ijerph16173143

9. D. Izvin, V. Lez'Er, A. Kopytova, MATEC Web of Conferences, 170, 01065 (2018) DOI: $10.1051 /$ matecconf/201817001065

10. A.V. Kopytova, N.S. Zotkina, I.G. Reshetnikova, MATEC Web of Conferences 239, 04012 (2018) DOI: 10.1051/matecconf/201823904012

11. T. Boeri, P. Garibaldi, Labour Economics 59, 33-48 (2019) DOI: 10.1016/j.labeco.2019.03.007

12. V. Lez'Er, N. Semerianova, A. Kopytova, Y. Truntsevsky, E3S Web of Conferences 110, 02093 (2019) DOI: 10.1051/e3sconf/201911002093

13. R. Balcerzyk, D. Balcerzyk, J. Ledzianowski, R. Siczek, AIP Conference Proceedings 2116, 180009 (2019) DOI: 10.1063/1.5114166

14. A. Gregorič, M.S. Rapp, Industrial Relations 58(3), 376-422 (2019) DOI: $10.1111 /$ irel.12241 
15. J.T. Bang, A. Mandal, A. Mitra Applied Economics Letters 26(9), 741-744 (2019) DOI: $10.1080 / 13504851.2018 .1494797$

16. A. Kopytova, MATEC Web of Conferences 106, 08056 (2017) DOI: 10.1051/matecconf/201710608056

17. S. Ojala, P. Pyöriä Scandinavian Journal of Public Health 47(3), 293-300 (2019) DOI: $10.1177 / 1403494818804106$

18. M. Fomina Corporate strategies, 46 (9762) (2018)

19. S. Slesarev Compensation for dismissal by agreement of the parties - will the employee become a victim of fraud? (GARANT.RU, 2018) [electronic journal, accessed 04.02.2020]

20. V.A. Lez'Er, N.A. Semeryanova, A.V. Kopytova, MATEC Web of Conferences, 239, 04027 (2018) DOI: 10.1051/matecconf/201823904027

21. S.M. Badriyah, R. Suharto, E. Susilowati, M.H.F. Allam, International Journal of Recent Technology and Engineering 8(4), 4196-4200 (2019) DOI: 10.35940/ijrte.D7776.118419

22. F. Belloc, Journal of Institutional Economics 15(2), c. 235-258 (2019) DOI: $10.1017 / \mathrm{S} 1744137418000139$ 